\title{
Sustainable Sources from Aquatic Organisms for Cosmeceuticals Ingredients
}

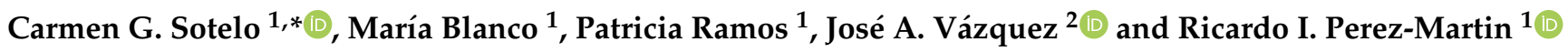 \\ 1 Food Biochemistry Group, Instituto de Investigaciones Marinas CSIC, 36203 Vigo, Spain; \\ mblanco@iim.csic.es (M.B.); ariza@iim.csic.es (P.R.); ricardo@iim.csic.es (R.I.P.-M.) \\ 2 Recycling and Valorisation of Waste Materials Group, Instituto de Investigaciones Marinas CSIC, \\ 36203 Vigo, Spain; jvazquez@iim.csic.es \\ * Correspondence: carmen@iim.csic.es; Tel.: +34-986214471
}

Citation: Sotelo, C.G.; Blanco, M.;

Ramos, P.; Vázquez, J.A.;

Perez-Martin, R.I. Sustainable Sources from Aquatic Organisms for

Cosmeceuticals Ingredients. Cosmetics

2021, 8, 48. https://doi.org/10.3390/

cosmetics 8020048

Academic Editor: Piera Di Martino

Received: 4 May 2021

Accepted: 4 June 2021

Published: 9 June 2021

Publisher's Note: MDPI stays neutral with regard to jurisdictional claims in published maps and institutional affiliations.

Copyright: (c) 2021 by the authors. Licensee MDPI, Basel, Switzerland. This article is an open access article distributed under the terms and conditions of the Creative Commons Attribution (CC BY) license (https:// creativecommons.org/licenses/by/ $4.0 /)$.

\begin{abstract}
Long life expectancy of populations in the developing world together with some cultural and social issues has driven the need to pay special attention to health and physical appearance. Cosmeceuticals are gaining interest in the cosmetic industry as their uses fulfills a double purpose: the requirements of a cosmetic (clean, perfume, protect, change the appearance of the external parts of the body or keeping them in good condition) with a particular bioactivity function. The cosmetics industry, producing both cosmetics and cosmeceuticals, is currently facing numerous challenges to satisfy different attitudes of consumers (vegetarianism, veganism, cultural or religious concerns, health or safety reasons, eco-friendly process, etc.). A currently growing trend in the market is the interest in products of low environmental impact. Marine origin ingredients are increasingly being incorporated into cosmeceutical preparations because they are able to address several consumer requirements and also due to the wide range of bioactivities they present (antioxidant, whitening, anti-aging, etc.). Many companies claim "Marine" as a distinctive marketing signal; however, only a few indicate whether they use sustainable ingredient sources. Sustainable marine ingredients might be obtained using wild marine biomass through a sustainable extractive fishing activity; by adopting valorization strategies including the use of fish discards and fish by-products; and by sustainably farming and culturing marine organisms.
\end{abstract}

Keywords: cosmetics industry; cosmeceuticals; marine ingredients; skin; anti-aging; biomass valorization; fish discards; fish by-products; sustainability; resilient marine ecosystem

\section{Introduction}

Cosmetics, as defined by the Cambridge Dictionary of English refers to "substances that you put on your face or body that are intended to improve your appearance". A more complete definition is provided by the European Commission (EC) regulation No. $1223 / 2009$ that defines cosmetics as "any substance or mixture intended to be placed in contact with the external parts of the human body (epidermis, hair system, nails, lips and external genital organs) or with the teeth and the mucous membranes of the oral cavity with a view exclusively or mainly cleaning them, perfuming them, changing their appearance, protecting them, keeping them in good condition or correcting body odours,". The word cosmeceutical originates from the combination of cosmetics and pharmaceutical; cosmeceuticals are also products that are applied topically as cosmetics but that contain specific ingredients that can improve biological function resulting in a healthier skin [1]. It is their bioactivity effects that makes that cosmeceuticals are gaining importance, as consumers require products with proved efficacy. Although the use of cosmeceutical is widespread nowadays, the definition of these two related words has been controversial for decades; nevertheless, at the moment and after several publications addressing the contention, more consensus seems to be reached. However, a legal definition does not exist yet [2,3]. The word cosmeceutical was first defined by Reed in 1962 and redefined 
by Kligman in 1993 describing it as a hybrid category between cosmetics and drugs with a pharmaceutical benefit. Nowadays, this definition includes a wider and more precise range of activities claiming a bioactivity effect [2,4-6].

Europe, including the UK, is the largest producer of cosmetic products of the world, at $€ 78.6$ billion, followed by USA with $€ 67.2$ billion [7]. The importance of the European cosmetic value chain is demonstrated also by its contribution, with a total of $€ 29.19$ billion to the gross value added (GVA), the largest contributors being France and Germany. Furthermore, it also creates 2 million direct, indirect, and induced jobs [7]. Europe is also an important market for cosmetics; the average expenditure of the European consumers is about $€ 135$ per person/year, with wealthiest countries like Norway or Switzerland spending up to $€ 225$ per person/year [7].

Although the above-mentioned numbers regarding the cosmetics product market are of significant importance, the global cosmeceutical market is also experiencing a constant increase, growing at a CAGR (compound annual growth rate) of around 7\% during 20142019 [8] and is expected to reach USD 98.7 billion by 2026.

The cosmetics industry, producing both cosmetics and cosmeceuticals, is currently facing a number of challenges, such as the need to meet some personal attitudes (vegetarianism or veganism); environmental, cultural, or religious concerns; and health or safety reasons, enumerating some of them. One of the current trends in the market is the growing interest for "green products", those that consumers associate with a lower environmental impact compared with traditional products [9].

Ingredients are very important for the industry, it must be highlighted that they are deeply related to some of the above-mentioned concerns, leading to a variety of products claiming to meet some requirements. Some examples include avoiding the use of mammalian proteins because of BSE (bovine spongiform encephalopathy) or some specific animals to comply with halal rules, vegan cosmetics that avoid any animal or animal-derived ingredients (i.e., honey or milk), etc. Sustainability, as mentioned before, is increasing in importance, and consumers are starting to be aware that circular economy principles should be used in the products they buy. Some cosmetics companies are practicing a vertical integration structure incorporating farms or agriculture businesses to test and secure ingredient sourcing; the movement towards a farm-to-face approach is steadily increasing in the industry [10].

It is widely known that marine environments have provided humans from prehistoric times with different food, ornaments, tools, cosmetic ingredients and even treatment for ailments [11,12]. Nowadays, there is a significant trend in the cosmetic industry to incorporate marine origin ingredients in their formulations, and moreover, many companies claim "Marine" as a distinctive marketing signal. Some of the compounds which may be found in the marine environment include antioxidants, tyrosinase inhibitors, anti-UV, sebum, and wrinkle regulators and may be included in different cosmeceuticals [13]. Some examples are brands that include marine bacterial fermentation products, different macroalgae and/or microalgae species extracts, collagen, minerals, etc.

In this scenario, it is considered that most marine derived ingredients are in a good position to address most of the challenges mentioned above, such as the integration of marine ingredient production and cosmetic industry.

Some research works have shown that marine biomolecules are useful as cosmeceutical ingredients, and in fact they are already being used by the cosmetic industry [14]. However, the sustainability of their sources and production practices has not been considered for decades an important aspect to be addressed. The new environmental policy and management trends, such as the EU newly reviewed Common Fishery Policy (CFP) [15] 2020 EU Strategy, and, more recently, the United Nations Sustainable Development Goals (SDG) [16] all underscore the importance of adopting sustainable fishing practices to protect marine and maritime environments, assuring sustainable development for future generations. The need to implement more sustainable practices in the fishery and aquaculture sector necessarily involves the valorization of by-products and discards. These biomasses 
could be used as a source of biomolecules for the cosmetics industry. For that to become a reality, these industries need to plan and improve the management of their by-products to obtain the best outcome in terms of product quality and revenue. Furthermore, the real uptake of these ingredients by the cosmetics industry involves several stakeholders; this requires that some of the following issues are coordinated and addressed appropriately:

1. correct identification of industry applications and demand for a particular ingredient

2. selection of marine ingredients must be based on the correct taxonomic identification and classification of marine species, otherwise the reproducibility of the extraction process (and therefore the claimed bioactivity) might be compromised

3. complying the rules of access and benefits sharing established in Nagoya protocol and sustainable sourcing of ingredients

4. competitive price $/ \mathrm{kg}$ of ingredients

5. information about the legislative requirements for a particular ingredient and application

6. efficient and environmentally friendly manufacturing process including a sustainable supply [13]

The objective of this review is to identify and analyze the main applications of marine cosmeceutical ingredients with a focus on anti-ageing properties and identify which are the main challenges for the sustainable production of these ingredients.

\section{Physiological and Environmental Factors Related to Skin Aging}

Nowadays, people are concerned when skin loses some of its more prominent characteristics, such as good hydration, elasticity, smoothness, and uniformity, among others. In these situations, most people rely in those products that they believe protect their skin from losing the youthful or healthy appearance of skin.

There are many circumstances that can alter the cultural-dependent perception of good skin appearance. In the case of developed countries, there is a strong tendency to associate negative considerations with elderly people, and that also includes the appearance of aged skin. Cosmeceuticals are products that are designed to address several skin problems, most of them related to environmental factors and aging [17].

Aging of skin is a complex process involving oxidative, epigenetic, and genotoxic stresses; telomere shortening; and mitochondrial dysfunction; causing skin cell senescence [18]. It has been proposed that skin aging is related to the alteration of the extracellular matrix (ECM) in both the dermis and epidermis. Although the dominant factor explaining the degradation of ECM is genetic, other external factors such as UV exposure or weather conditions have also been shown to contribute significantly to this change [19].

Reduction of skin thickness caused by a slower epidermal cell turnover with age is another important alteration occurring in skin aging. It is accompanied with the loss of elasticity, mainly caused by a decrease in fibroblasts (the cell types responsible for collagen and elastin synthesis) but also by the structural alteration of elastic fibers [17]. These changes result in skin fragility, skin wrinkling, and decreased elasticity.

Collagen (type I and III) and other elastic fibers are main structural components of most animal tissues. In the case of skin, these fibrillar proteins form a network that is firmly attached to the dermal-epidermal junction [20]. However, during intrinsic aging, this network losses its original reticular pattern and evolves to a wider one, whereas extrinsic aging adds up to collagen loss, bigger changes in network organization and crosslinking, and modification of amino-acid side chains [21,22]. One of the main culprits of these changes are oxidation pathways that generate reactive oxygen species (ROS), namely metabolism and exposure to UV radiation. Ultimately, oxidation leads to inflammation and increased activity of neutrophils, elastases, and matrix metalloproteases (MMPs), which are the proteases responsible for collagen hydrolysis (Figure 1). 


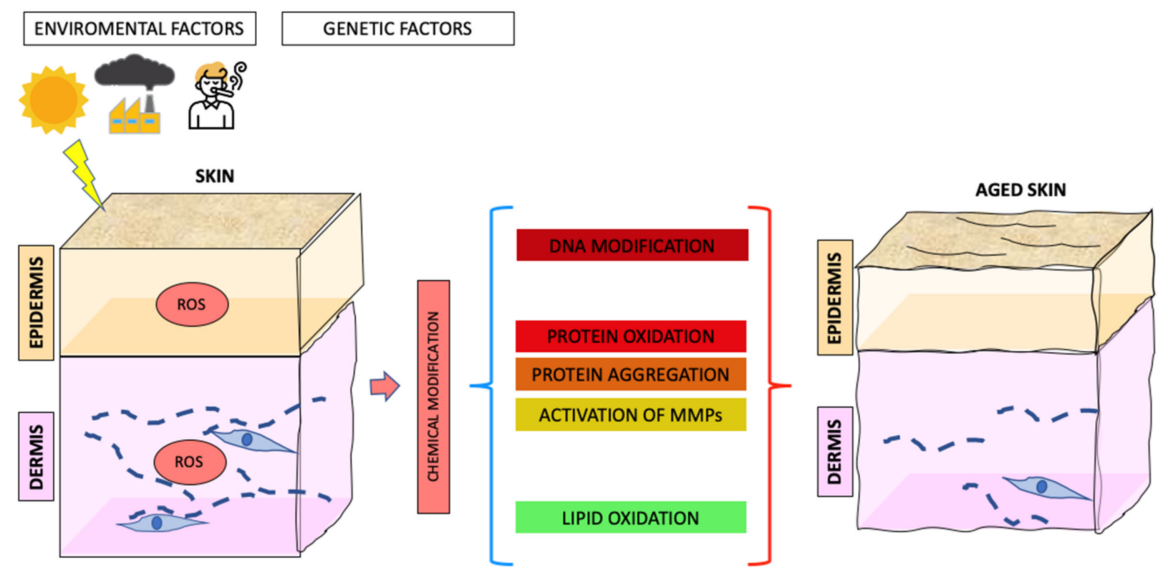

Figure 1. Main factors involved in skin aging and consequences leading to aged skin.

The main consequence of these changes is the aging of skin, and this usually means the apparition of wrinkles, pigmentation spots, skin laxity and thinning, dryness etc. [23].

Different cosmeceuticals include ingredients that may play a role in fighting some of these problems. Marine ingredients have gained importance as cosmeceutical ingredients, and in the following sections we will review the foremost that are being included in this type of products.

\section{Marine Cosmeceutical Ingredients}

Many different marine organisms contain diverse compounds that exhibit interesting properties to be used by the cosmetics industry. Those which are already being commercialized are showed in Table 1. Some previous reviews have reported different compounds and their potential applications in cosmetics.

Table 1. Cosmetic companies that use marine cosmeceutical ingredients in their products.

\begin{tabular}{|c|c|c|c|c|}
\hline Products & Ingredient & Source & Company & Cosmetic Benefits \\
\hline Eleana & Marine collagen & Marine sponge & $\begin{array}{l}\text { www.klinipharm. } \\
\text { com/ }\end{array}$ & $\begin{array}{l}\text { Reduces appearance of wrinkles. } \\
\text { Combats skin damage from free } \\
\text { radicals and inflammation. }\end{array}$ \\
\hline $\begin{array}{l}\text { Rose Plus Marine } \\
\text { Collagen Complex }\end{array}$ & Marine collagen & Marine collagen & $\begin{array}{l}\text { www. } \\
\text { theorganicpharmacy. } \\
\text { com/ }\end{array}$ & $\begin{array}{l}\text { Reduces fine lines by stimulating } \\
\text { elastin and collagen production to } \\
\text { achieve silky smooth skin. }\end{array}$ \\
\hline Salmonollagen & Marine collagen & Salmon skin & www.finncanada.com/ & $\begin{array}{l}\text { Penetrates deep into the skin and } \\
\text { improves skin condition from } \\
\text { inside. }\end{array}$ \\
\hline TetraSOD $^{\circledR}$ & $\begin{array}{l}\text { Superoxide } \\
\text { dismutase }\end{array}$ & $\begin{array}{l}\text { Marine } \\
\text { phytoplankton } \\
\text { (Tetraselmis chuii) }\end{array}$ & www.tetrasod.com/ & $\begin{array}{c}\text { Antioxidant and } \\
\text { anti-inflammatory action. } \\
\text { Preventive and corrective effects to } \\
\text { control ROS. }\end{array}$ \\
\hline Eclae & Carotenoids & $\begin{array}{c}\text { Marine } \\
\text { phytoplankton } \\
\text { Dunaliella salina) }\end{array}$ & www.eclae.com/en/ & $\begin{array}{l}\text { Produces a large amount of } \\
\text { carotenoids. Enhances the } \\
\text { anti-aging effects. }\end{array}$ \\
\hline Abyssine & Exopolyssacharides & $\begin{array}{l}\text { Alteromonas } \\
\text { ferment extract }\end{array}$ & www.unipex.com/ & $\begin{array}{l}\text { Targeting and reducing irritation } \\
\text { of sensitive skin }\end{array}$ \\
\hline Refirmar & Protein mixture & $\begin{array}{l}\text { Pseudoalteromonas } \\
\text { sp. }\end{array}$ & https://bioalvo.com/ & $\begin{array}{l}\text { Hydrating, anti-wrinkle, } \\
\text { expression line attenuator. }\end{array}$ \\
\hline SeaCode & Glycoproteins & $\begin{array}{l}\text { Pseudoalteromonas } \\
\text { sp. }\end{array}$ & https:/ /lipotec.com & Cellular protein maintenance. \\
\hline
\end{tabular}


Table 1. Cont.

\begin{tabular}{|c|c|c|c|c|}
\hline Products & Ingredient & Source & Company & Cosmetic Benefits \\
\hline Resilience & $\begin{array}{l}\text { Tricyclic diterpene } \\
\text { glycoside }\end{array}$ & $\begin{array}{l}\text { Pseudopterogorgia } \\
\text { elisabethae }\end{array}$ & https://esteelauder.es & $\begin{array}{c}\text { Anti-inflammatory and analgesic } \\
\text { agent to prevent irritation caused } \\
\text { by exposure to sun. }\end{array}$ \\
\hline Alguronic & Alguronic acid & Marine microalgae & www.algenist.com/ & $\begin{array}{l}\text { Improves overall skin health and } \\
\text { firmness. Minimizes the } \\
\text { appearance of fine lines. }\end{array}$ \\
\hline Dermochlorella DG & Oligopeptides & $\begin{array}{l}\text { Marine microalga } \\
\text { (Chlorella sp.) }\end{array}$ & $\begin{array}{l}\text { www.codif-reserche-et- } \\
\text { nature.com/ }\end{array}$ & $\begin{array}{l}\text { Increases firmness and skin tone. } \\
\text { Erases vascular imperfections. }\end{array}$ \\
\hline Helionori ${ }^{\circledR}$ & MAAs & $\begin{array}{c}\text { Red algae (Porphyra } \\
\text { umbilicalis) }\end{array}$ & www.gelyma.com/ & $\begin{array}{l}\text { Supplies natural skin protection } \\
\text { against sun burn cell formation. }\end{array}$ \\
\hline Helioguard $^{\mathrm{TM}} 365$ & MAAs & $\begin{array}{l}\text { Red algae (Porphyra } \\
\text { umbilicalis) }\end{array}$ & $\begin{array}{l}\text { www. } \\
\text { mibellebiochemistry. } \\
\text { com/ }\end{array}$ & $\begin{array}{l}\text { Natural UVA protection. Protects } \\
\text { the skin against premature aging } \\
\text { signs. Prevents the appearance of } \\
\text { lines, wrinkles, and other signs of } \\
\text { photo-aging. DNA-protection. }\end{array}$ \\
\hline $\begin{array}{l}\text { Collagen } \\
\text { moisturizer }\end{array}$ & Marine collagen & Fish skin & www.seanergy.es / & $\begin{array}{l}\text { Prevents the formation of wrinkles } \\
\text { and provides tissues resistance. }\end{array}$ \\
\hline $\begin{array}{l}\text { Collagen } \mathrm{HM}^{\mathrm{TM}} \text { Sol } \\
\text { Elastin } \mathrm{TM}^{\mathrm{TM}} \\
\text { Glycosann }{ }^{\circledR} \text { sol } \\
\text { Protein } \mathrm{M}+{ }^{\mathrm{TM}}\end{array}$ & $\begin{array}{l}\text { Hydrolyzed marine } \\
\text { collagen Marine } \\
\text { elastin Marine } \\
\text { chondroitin } \\
\text { sulphate Marine } \\
\text { cartilage extract }\end{array}$ & Fish by-products & www.copalis.fr/ & $\begin{array}{l}\text { Moisturizing, cell regeneration, } \\
\text { firmness and elasticity, anti-age } \\
\text { and anti-wrinkle. }\end{array}$ \\
\hline $\begin{array}{l}\text { Hydrolyzed Fish } \\
\text { Collagen }\end{array}$ & $\begin{array}{l}\text { Hydrolyzed Fish } \\
\text { Collagen }\end{array}$ & Fish skin & $\begin{array}{l}\text { www.kenneyandross. } \\
\text { com/ }\end{array}$ & $\begin{array}{l}\text { Helps promote healthy skin, nails, } \\
\text { hair, and joints. }\end{array}$ \\
\hline
\end{tabular}

\subsection{Proteins: Collagen, Collagen Hydrolysate, and Marine Origin Peptides}

Proteins have been used in cosmetics since ancient times. Some well-known examples are donkey or camel milk used by some cultures in Africa. Their role as a cosmeceutical depends on the type of protein; however, most of them are used for their water-binding and protective properties in cleansing, conditioning, and hydrating in cosmetics, and some in cosmeceuticals as antiaging ingredients [24].

As has been mentioned above, collagen is one of the most relevant proteins involved in maintaining skin appearance and therefore is one of the main ingredients present in cosmeceuticals, especially in those with antiaging properties. Collagen is the main structural protein in connective tissue of all animals, showing a particular heterotrimeric arrangement that confers unique physiological functions to the tissues where it is present $[25,26]$. The collagen protein family is diverse, including up to 26 different types [27] with the fibril forming Type I being one of the more studied and used for cosmeceutical applications [27-29]. The fibrillary structure of collagen is responsible for its suitability for cosmeceutical uses due to its anti-aging and anti-wrinkling capacity.

The industrial production of collagen is mostly based on terrestrial farm animals, and the main product is gelatin, which is the denatured and fragmented collagen form that is easier to handle and has many different applications [30]. Approximately $80 \%$ of edible gelatin produced in Europe is made from pork skin [31]. However, the production and usage of collagen from aquatic organisms is increasing and is based on the existence of a significant amount of by-products resulting from the fish processing industry, which can be fully used to increase the sustainability of the fishery and aquaculture industries [32]. Moreover, this increase has been also fostered by sanitary outbreaks (bovine spongiform encephalopathy), religious concerns (Halal, Kosher) or feed habits (pescatarians), all of them not accepting of different animal species. 
Collagen from aquatic organisms presents excellent functional and safe (low antigenicity) characteristics and is becoming an ingredient widely included both in cosmetics and in cosmeceuticals due to its significant benefits as a natural humectant or moisturizer, as well as its preventing water loss or photoaging [29,33,34].

Marine collagen is principally obtained from the skin of different fish species including teleosts and chondrichthyes $[29,35,36]$, although it has also been extracted from other sources such as bones, fins, or scales [37-40] and also from invertebrates such as sponges or jellyfish $[19,41]$.

Marine collagen derived peptides produced by controlled hydrolysis have been also obtained for their interesting bioactivities such as antioxidant, anti-inflammatory, reduction of melanin synthesis, tyrosinase or matrix metalloproteinase inhibition, with applications in development of cosmeceuticals against aging and skin wrinkles [42]. Moreover, some other fish-derived peptides have been shown to inhibit MMPs, which have been associated with skin aging, as mentioned above. These peptides have been characterized and have shown the potential to inhibit MMPs; however, although effective, their sourcing from fish does not seem feasible, since they are present in very low amounts [43].

There are some examples of cosmetic companies that include marine collagen in their cosmeceuticals. Eleana is a product from Klinipharm [44] that contains collagen microspheres from sponges, claiming to have anti-aging properties.

Rose Plus Marine Collagen Complex is an anti-aging serum from "the organic pharmacy" that claims to stimulate skin collagen and elastin. This formula contains atelocollagen from marine origin combined with different plant oils [45].

Finncanada uses wild salmon skin collagen ("salmonollagen") from Pacific waters using an alkaline extraction procedure; they claim that this process, unlike the widely known acid extraction process, results in an improved product that, combined with minerals, amino acids, and vitamin C, repairs skin and presents anti-aging properties [46].

\subsection{Enzymes}

As has been mentioned above, reactive oxygen species (ROS) are involved in different damaging processes, causing alterations in the normal functioning of the biological systems, the skin being one of them. All living beings need to cope with the damaging reactions provoked by ROS, and for that they use two strategies: one is producing molecules with antioxidant properties and the other with enzymes that catalyze the transformation of ROS into non-damaging substances. The most important enzyme with such properties is superoxide dismutase (SOD; EC1.15.1.1). SOD catalyzes the conversion of the oxygen anion into hydrogen peroxide and oxygen [47].

Marine SODs have been described in a variety of organisms covering the whole spectra of marine life, from bacteria up to vertebrates [47]. Marine environments with highly oxidizing conditions (high irradiations, high concentration of metal ions, etc.) produce SODs with specific biochemical features, such as specific activities, temperature ranges, and $\mathrm{pH}$ stability, that might be of interest in different applications. The isolation and biochemical characterization of marine SODs have shown a diversity of features that might be used for different human applications.

In the case of skin protection, it has been already mentioned above that ROS might have a role in altering the structure of collagen fibers, leading to a weaker dermis and consequently the appearance of wrinkles and loose skin. It has been shown that extracellular SOD may protect collagen type I from oxidation and fragmentation by binding to collagen molecules [48] and therefore protecting them from oxidation damages.

Some companies are extracting SOD from microalgae, and one example is TetraSOD [49], which obtains a SOD extract from the cultivated phytoplankton Tetraselmis chuii. This species produces three different isoforms of SOD that each have a different metal cofactor: $\mathrm{Mn}, \mathrm{Cu}-\mathrm{Zn}$, and Ni. The high SOD activity displayed by Tetraselmis chuii is claimed to derive from the combination of these three SODs. The product has been tested for the improvement of physical performance of athletes who can take it as an oral supplement. 
The application as a cosmeceutical ingredient might be tested to evaluate the potential for reversing ROS incidence in skin aging.

\subsection{Lipids: PUFAS, Squalene}

Lipids are commonly used for restoring water loss from the epidermis. Some lipids, such as sphingolipids, are part of the physical barrier, in particular of the bilayers of lipids (lamellae), which maintain adequate humidity of the stratum corneum in skin epidermis. In addition, some polyunsaturated fatty acids (PUFA), such as linoleic acid (18:2n-6), gammalinolenic (18:3n-6), which is abundant in plants, and eicosapentaenoic acid (EPA; 20:5n-3) and docosahexaenoic acid (DHA; 22:6n-3), which characterize the fatty acid composition of marine organisms, have an important role in reducing inflammatory pathways at the skin level [50]. Microalgae such as Tetraselmis suecica, Porphyridium cruentum, and Chaetoceros calcitrans produce significant amounts of arachidonic (20:4n6) and linolenic acids (18:3n6), while Nanochloropsis sp. and Isochrysis galbana, EPA and DHA, respectively [51]; macroalgae, such as Laminaria, are also rich in omega 6 fatty acids. Another example of interesting filamentous macroalgae is the Cladophora glomerata, which contains unsaturated fatty acids C16:1 (n-7) and C18:1 (n-3), acting as an emollient and protector of water skin loss [52,53]. Based on these studies, it can be assumed that in general, lipids from marine organisms can represent a value for their use as ingredients in cosmeceutical formulations as moisturizing agents to preserve normal skin appearance [19].

Another important compound in the protection of skin is squalene. Squalene is a triterpenoid that is produced by the sebocytes present in the dermis. Squalene helps to maintain the hydration of the skin and, most importantly, protects the skin from the oxidation caused by UV. The mechanism of this protection is by oxidation and decomposition of squalene itself and the production of low molecular weight oxidation compounds [54]. Other authors posited that squalene is resistant to peroxidation, and therefore its role as antioxidant is linked to this capacity of disrupting peroxidation chain reactions [55].

Since squalene natural production decreases with age, it has been identified as an interesting compound for cosmeceutical applications, especially those formulations that aim to fight UV damage, but also in moisturizing applications. Squalene sourcing relies on certain shark species livers, where can be very abundant. However, more recently and due to conservation concerns, the industry is changing this origin towards those coming from vegetables such as amaranth with a very high amount of this compound [55].

\subsection{Carotenoids}

Carotenoids are associated with different colors, such as yellow, orange, and red, in different organisms. They are a class of terpenes; two major classes of carotenoids can be differentiated: carotenes, with only hydrocarbon chains; and xanthophylls, which are like carotenes but with oxygen molecules.

In the marine environment, carotenoids can be found in macro and microalgae and some other different aquatic organisms, such as crustaceans, mollusks, and fish [56]. However, carotenoids are only synthesized by photosynthetic organisms, in the case of the marine environment, mainly by macro and microalgae, bacteria, and fungi. Carotenoids exhibit a marked antioxidant character, and they protect against UV damage, decreasing the impact of ROS and free radicals. Given these features, carotenoids are being used by the cosmetics industry mainly in sun protection creams and, because of their color, in tanning lotions $[57,58]$.

Some microalgae species, such as Dunaliella salina, have shown high concentrations of beta-carotene [59]. Extracts of this species have been traditionally used in natural origin cosmeceuticals and nowadays are commercially used by the cosmetics industry [60]. Another example of microalgae as a source of carotenoids is Haematococcus fluvialis that, in some restrictive conditions, may accumulate high amounts of Astaxanthin, this compound being a very potent antioxidant used in UV-protecting cosmeceuticals [59]. 
In the case of macroalgae, fucoxanthin, an orange xanthophyll, is the most important carotenoid. This compound can be found abundantly in several brown algae such as Undaria pinnatifida, Hijikia fusiformis, Laminaria japonica, Sargassum sp., and Fucus sp. [61,62].

The most interesting method for the extraction of carotenoids is to use supercritical fluid extraction (SFE). Using $\mathrm{CO}_{2}$ in combination with some other polar solvents, such as ethanol, improves the carotenoid extraction efficiency and makes SFE a green procedure appropriate for the industrial extraction of these compounds [61].

\subsection{Polysaccharides: HA, Glycogene, Sulphated Polysaccharides, Chitin, and Chitosane}

Polysaccharides (PS) present some characteristics that make them suitable for cosmetic applications, such as emulsifying capacity and thickening and gel formation, but also for cosmeceutical applications, such as protection, stimulation of collagen, or hyaluronic acid synthesis [19].

Different types of PS can be used as ingredients: polysaccharides and exopolysaccharides from different origins, glycogen, chitin and chitosan, and hyaluronic acid [63,64].

Exopolysaccharides (EPSs) are mainly found in different bacteria species. Some of these EPSs have shown interesting properties for cosmeceutical use, for example Deepsane isolated from Alteromonas macleodii living in a deep hydrothermal vent. [65]. This compound protects keratinocytes and Langerhans cells from inflammatory and UV damage. The compound is marketed as a cosmeceutical with the name of Abyssine [66]. Other examples of commercialized products containing cosmeceuticals are Refirmar [67] and Sea Code [68], both obtained from the fermentation of Pseudolateromonas sp. strain. Resilience contains an extract of Pseudopterogorgia elisabethae that is used in cosmetics as a powerful antiinflammatory [69]. There are more examples of EPSs produced mainly by bacteria living in harsh environments that are being used by the cosmetic industry [70].

Microalgae are also sources of PS. An example is the "Alguronic" extract marketed in Algenist (Solazyme Company, San Francisco, CA, USA) [71], which claim to contribute to the regeneration of the extracellular matrix by stimulating the synthesis of elastin and collagen. Another example is Dermochlorella DG ${ }^{\circledR}$ from CODIF Reserche \& Nature, using Chlorella sp. extract for increasing firmness and skin tone [72].

Macroalgae, such as brown algae, contain fucoidan, a highly branched sulphated and acetylated polysaccharide with L-fucose. This substance has skin-protecting, antioxidant, and anti-aging properties, making it a good candidate for being a cosmeceutical ingredient [73].

Another interesting compound is alginate, a PS obtained from brown seaweeds, that has been reported to form hydrogels in the presence of $\mathrm{Ca}^{2+}$ ions that can be then shaped as microbeads, using electrospray, for being a biodegradable alternative to scrubbing additives in cleansers [74].

Hyaluronic acid (HA) is synthesized by human dermal fibroblasts and plays an important role in the maintenance of skin structure and hydration [75]; the combination of HA and collagen peptides have shown an increase in the proliferation of dermal fibroblast in cell cultures [76]. A few works have investigated the possible sourcing of HA from marine organisms; low-molecular weight HA has been isolated from the Mediterranean mussel (Mytilus galloprovincialis), high-molecular-weight HA from stingray (Aetobatus narinari) liver [75], and high-molecular weight and purity HA from fish eye-balls (Xiphias gladius and Prionace glauca) [77]. Additionally, some marine bacteria are able to produce hyaluronic acid by a fermentative process [51], and Vazquez et al. [78] used marine peptones obtained with fishery by-products to produce HA with a fermentative process using Streptococcus zooepidermicus.

Glycogen is a glucose polysaccharide that provides energy to animals, fungi, and bacteria; it can be obtained from various marine sources such as oyster pearls, mantle scallops, or some species of mussels, and its high moisturizing potential make it very suitable for use in the cosmetics industry [79-81]. 
Chitin and chitosan are polysaccharides that can be obtained from a number of marine organisms such as crustaceans and mollusks. Chitin is a polymer of glucosamide and $\mathrm{N}$-acetylglucosamide and is insoluble in aqueous solution, while chitosan is the $\mathrm{N}$ deacetylated form of chitin produced by chemical or enzymatic deacetylation of chitin and is soluble in acid aqueous solutions. These compounds have a number of applications such as UV protection, cleansing, conditioning, smoothing, moisturizing, and antioxidant $[2,82]$.

\subsection{Tyrosinase Inhibitors}

Hyper-pigmentation of skin is caused by an increase of melanin due to several factors, such genetics, excessive sun exposure, age, etc. Tyrosinase is the main enzyme involved in melanogenesis [83], and therefore the cosmetics industry is interested in finding appropriate compounds that downregulate melanogenesis [84].

Extracts from marine plants and algae have been reported as inhibitors of tyrosinase activity $[83,84]$. The combination of a phlorotanin-rich extract of a brown alga, Ecklonia cava, a fucoidan-rich extract of Undaria pinnatifida, and glycosaminoglycans (GAGs) of a tunicate mixed in a proportion of 5:4:1 produced a non-toxic decrease of melanogenesis in mouse melanoma cells [84]. In another study, the methanol extracts of Phyllospadix iwatensis, a marine sea-grass species containing two sulphated flavonoids, especially luteolin 7sulphate, inhibited human tyrosinase and also impacted the expression of proteins involved in melanogenesis [83].

Gagunin D, a modified verrucosane diterpenoid isolated from a sponge, has shown not only inhibition of tyrosinase activity but also the suppression of the expression of other proteins involved in melanogenesis [85].

\subsection{Others}

The number of compounds isolated and characterized in the marine environment with applications as cosmeceuticals is increasing. In this section, some of other compounds with interesting features are briefly reviewed.

Mycosporine and mycosporine-like-amino acids (MAAs) have gained much attention due to their effectiveness in the absorption of UV radiation in many marine organisms [86]. These compounds were discovered in fungi in 1965, and it has been shown that marine bacteria and fungi synthesize them while others accumulate them [86]. These compounds, specially MAAs, present several advantages compared with other UV filters. They are natural and harmless to the environment like the synthetic filters or $\mathrm{TiO}_{2}$ nanoparticles, and moreover they exhibit absorbance in the wide range UV spectrum and do not generate harmful ROS. However, although there are some patents for the cosmeceutical application of these compounds obtained from marine organisms [87], only a few companies, such as Gelyma or Mibelle Biochemistry, produce sun care products, such as Helionori®or Helioguard ${ }^{\mathrm{TM}}$, which contain MAAs from the red algae Porphyra umbilicalis $[53,88,89]$.

The combination of algae, such as those present in commercial products like DERMOCEA, namely Meristotheca dakarensis and Jania rubens, has been attributed the capacity to stimulate keratin, glycosaminoglycans, and collagen type I and III synthesis [19]. Other algae, such as the brown algae Macrocystis pyrifera, may also stimulate the synthesis of hyaluronic acid [19], which also plays a role in skin appearance.

\section{Sustainable Sourcing of Cosmeceutical Ingredients from Aquatic Organisms}

One of the most important aspects of the production of cosmeceutical ingredients from marine organisms and which has not been sufficient addressed is their sustainable sourcing.

The chemical and functional characterization of marine cosmeceutical ingredients has been often the topic of different research works, as was shown above. However, most of these works did not discuss other relevant aspects, such as the potential volumes of raw material for the ingredients production, their abundance and location (i.e., availability of specific by-products in different geographic areas), cost-effectiveness, or whether they are obtained using sustainable/green extraction methods or from sustainable sources. Raw 
material costs are essential to decide whether or not an industrial process will be feasible at least in the short term; if the source of the compound is expensive, it will not likely be taken up by the industry because it will significantly impact the final price of the product.

From a sustainability point of view, some of the marine organisms that can be used as sources of cosmeceutical ingredients can be species already exploited by the fishery industry. During the last 50 years, the fishery industry has increased pressure on marine resources, leading to the increase of the percentage of stocks that are being exploited beyond their sustainable levels. However, nowadays there is growing concern about the negative effects of such practices on the oceans. There is global awareness about the need to manage marine resources, protecting both their diversity and population's health for future generations. Some international governmental and non-governmental organizations have developed and launched different management strategies/policies, such as the newlyreviewed EU Common Fishery Policy (CFP), Blue Growth strategy, 2020 EU Strategy, and, more recently, the United Nations Sustainable Development Goals (SDG), aiming to develop and implement sustainable socioeconomic and environmental world growth approaches. Specifically, some of the SDG are focused on the development of sustainable socioeconomic and environmental growth in the marine and maritime sectors.

As was mentioned before, a better use of the resources involving the reduction of waste and the full use of by-products may contribute to the implementation of some of these policies. The biotechnological transformation of marine discards and by-products may contribute to the isolation/production of molecules showing antioxidant, anti-inflammatory, antifouling, anti-cancer, etc., properties that could be used in a diverse array of applications including food, pharmaceutical, nutraceutical, and cosmetics industries. The so-called blue economy can take advantage of the valuable properties found in marine organisms, fostering the development of innovative markets that may fully use marine resources, thus contributing to conserving and sustainably using the oceans, seas, and marine resources for resilient and sustainable development, which is the objective of Sustainable Development Goal 14 of the United Nations.

Raw materials from marine organisms could be sustainably obtained by different approaches: using wild marine biomass through an extractive fishing activity, adopting valorization strategies including the use of fish discards and fish by-products, and by farming and culturing marine organisms (Figure 2).

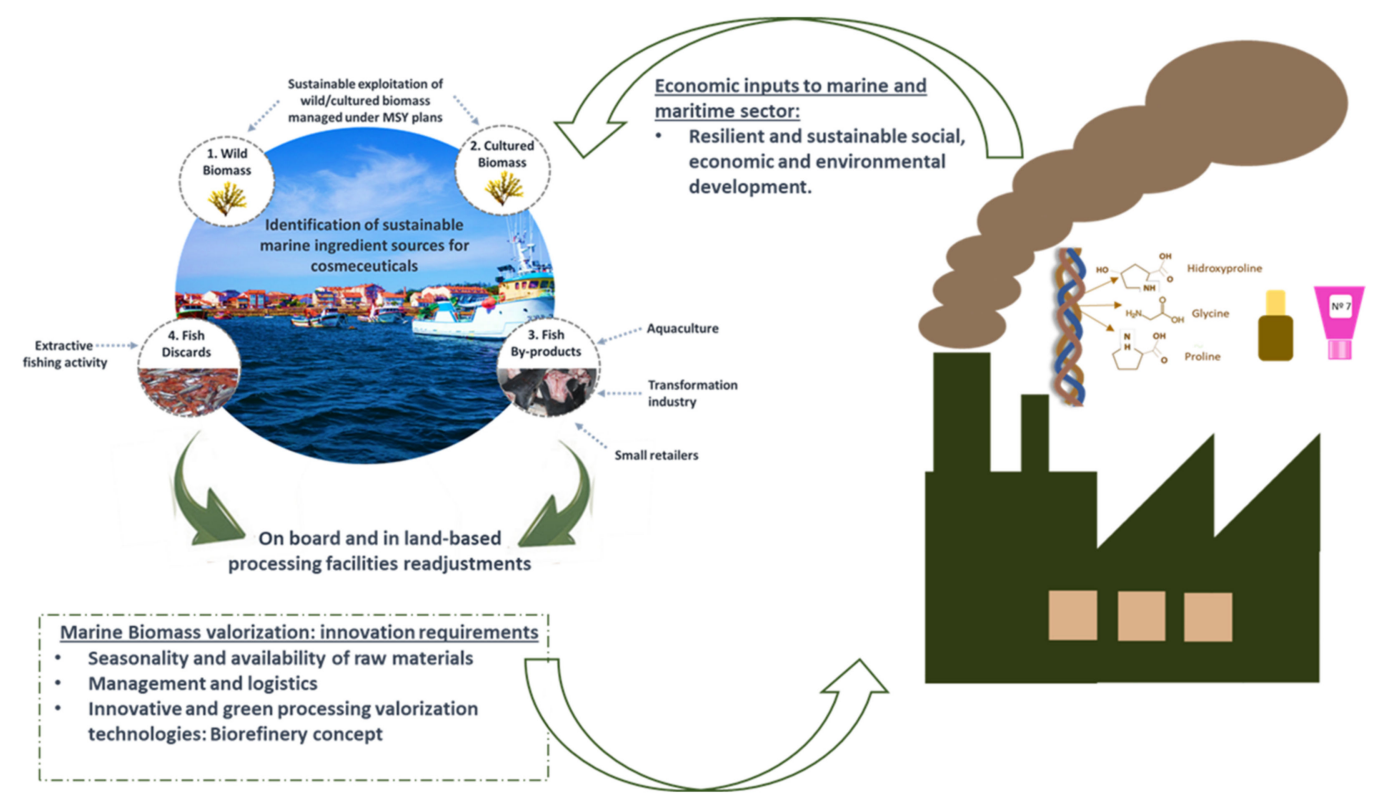

Figure 2. Sustainable production of marine cosmeceutical ingredients. 
Seaweeds are one of the major wild marine resources used nowadays for the extraction of cosmeceutical compounds, as several of its molecules have demonstrated high potential as active ingredients as well as to contain key elements for product consistency [90]. Although nowadays the global seaweed industry is worth more than USD 6 billion per year, most of its production, around $85 \%$, is intended for human consumption [12]. In 2016, total seaweed production accounted for 31.2 million tons $(\mathrm{mt})$ of which the culture sector contributed $30.1 \mathrm{mt}$, while the harvest from the wild was only $1.1 \mathrm{mt}$ [91]. Worldwide seaweed aquaculture is led by China, followed by Japan and Korea. Europe is still an emerging industry with only a small number of commercial seaweed farms [92]. Seaweed harvesting or culturing intended for cosmeceutical uses only represent a minor percentage of total production [93]; however, clearly, it is a non-stop growing industry, which indeed faces new challenges such as the need for adopting sustainable exploitation procedures managed under maximum sustainable yield plans within a circular economy approach, contributing to a resilient and sustainable marine and maritime sector [94]. Different species of macroalgae such as Gracilaria spp. or Fucus vesiculosus are examples of seaweed cultured as sources of bioactive compounds, such as agar and fucoidans, respectively, useful ingredients in different cosmetics preparations (shampoos, soaps, or facial masks, etc.), acting as a whitening agent or enhancing dermal fibroblast proliferation and deposition of collagen, for example [95,96]. Asparagopsis spp. or kelp aquaculture are other example of macroalgae extensively cultured to produce different cosmeceutical extracts [97].

Jellyfish is another example of marine organisms which could be harvested from the oceans or cultured as sources of cosmeceutical ingredients. The jellyfish aquaculture activity for cosmeceutical uses represents only an incipient activity because the majority of its production is intended for food consumption. However, there are several studies concluding that increased use of wild jellyfish as a source for cosmeceutical ingredients (i.e., collagen) would help to reduce the environmental, social, and economic problems causing by their blooms, representing a sustainable source for such ingredients [98,99].

Biocompounds with interesting applications as cosmeceutical might also be sustainably obtained from fish ex-discards and fish by-products. In 2013, EU Regulation No. $1380 / 2013$ [15] established as an objective the progressive elimination of fish discards by introducing the obligation to land all specimens of all species under TAC regulations (TAC: total allowance captures). The new policy also prohibits the use of catches below Minimum Conservation Reference Size (MCRS) for human direct consumption. Although incentives should be focused on minimizing and avoiding unwanted catches, specimens of species below MCRS are still expected, depending on several factors, such as area, time of the year, or type of fishery/gear. We define fish ex-discards as the fraction of the fishery capture which has to be retained on board and landed but cannot be used for direct human consumption, namely individuals of species subjected to quota regulation with sizes lower than permitted. Fish by-products are non-used/underused marine biomass resultant of the fish processing activity (filleting, freezing, or canning), but also generated in the aquaculture industry and in small retailers such as fish mongers, and which is mainly composed of bone frames, heads, skins, or viscera, representing up to 75\% of the fish weight [100-102]. Both fractions have been long-time considered as low value-added materials; however, nowadays there is an extensive literature highlighting their great potential as an excellent and sustainable source of new interesting biomolecules [59,103-107].

Using discards and by-products as raw materials for their biotechnological conversion into biomolecules of interest necessarily requires technical, management, and logistic readjustments, both in fishing fleets and in on-land facilities, with the objective of separating, classifying, stabilizing, and preserving them in the appropriate conditions for being transported to the industrial processing plants [108]. Other factors influencing the feasibility of fish discards and by-product valorization strategies include raw material seasonality, availability, and accumulation analysis; the existence of prospective studies analyzing different valorization alternatives; the support of government policies fostering innovative and green processing valorization technologies, which ideally should converge into a biore- 
finery concept industry; and, finally, having market studies of the potential biomolecules obtained. Despite extensive research regarding extraction and characterization of a wide range of biomolecules with very interesting bioactive properties, nowadays, and to our knowledge, there are only a few examples of solid industrial bioprocess using raw materials from discards or by-products for obtaining cosmeceutical ingredients. Copalis Sea Solutions (Le Portel, France) is one of those companies addressing sustainable development with an economic model based on a circular economy. Copalis develops natural cosmetic active ingredients (collagen, elastin, and chondroitin sulphate) with scientifically proven activity to keep skin young and healthy, using fish by-products [109].

Juncà Gelatines (Girona, Spain) and Biotech Invest (Faroe Islands) have created Seanergy a company located in the Faroe Islands that uses skin by-products of different fish species, such as cod, haddock, or saithe, generated locally for obtaining collagen with potential cosmeceutical applications [110].

Kenney and Ross Ltd. is a Canadian manufacturer and international exporter company which employs the skin of deep-sea wild fish generated as by-products in different fish processing facilities to produce hydrolyzed collagen with application in cosmeceuticals, as it helps to promote healthy skin, nails, or hair [111].

Much work is needed in the future, including stronger cooperation between all stakeholders involved in marine and maritime sectors, to address all the issues involved in the successful and sustainable management and industrial biotechnological transformation of raw marine biomasses, which permits the objectives of a sustainable circular economy to be accomplished while enhancing the economic benefits of the fishery sector.

\section{Conclusions}

- Cosmetics and cosmeceuticals are increasingly being demanded by consumers, especially for the prevention and improvement of skin aging signs. Aging is a complex process involving external and genetic factors. In general, oxidative stress and the subsequent alteration of the extracellular matrix, are the main problems. Nowadays, the industry is looking for bioactive ingredients with specific functions to modify these molecular mechanisms to produce cosmeceuticals.

- One of the challenges of the cosmetics industry is that consumers are increasingly demanding cosmetics and cosmeceuticals from companies that care about their environmental concerns, provide information about ingredient sources, in some cases have products that do not contain animal origin ingredients, or assure that certain cultural and religious concerns are addressed.

- Marine origin cosmetic ingredients are well accepted by consumers; in fact many compounds of interest as cosmeceutical ingredients are present in different marine organisms, from bacteria and algae up to invertebrates and vertebrates; however, sourcing of these ingredients should take into account several aspects, such as sustainable sourcing, use of fishery and aquaculture by-products to produce ingredients, compliance with Nagoya protocol and other legislative requirements, and efficient and environmental friendly processes

- Integration of fishery and aquaculture industry activities and companies producing cosmeceutical ingredients is needed; this integration should foster the implementation of circular economy principles in the cosmetic value chain, aiming as much as possible to use by-products to obtain bioactive ingredients for cosmetics and cosmeceuticals. Furthermore, the development of environmentally friendly processes to extract cosmeceutical ingredients from marine ingredients should be also addressed.

Author Contributions: Original draft preparation, C.G.S., M.B., and P.R.; Writing, review and editing, C.G.S., M.B., and P.R.; Review and editing, R.I.P.-M. and J.A.V.; Project administration, R.I.P.-M. and J.A.V.; Funding acquisition, R.I.P.-M. and J.A.V. All authors have read and agreed to the published version of the manuscript. 
Funding: This research was funded by the project CVMAR+i (Interreg POCTEP, Inovaçao industrial através de colaboraçoes específicas entre empresas e centros de investigaçao no contexto de valorizaçao biotecnológica marinha, grant number 0302_CVMAR_I_1_P, 2015).

Institutional Review Board Statement: Not applicable.

Informed Consent Statement: Not applicable.

Data Availability Statement: Not applicable.

Acknowledgments: We acknowledge Tiago H. Silva for the CVMAR+I project coordination support.

Conflicts of Interest: The authors declare no conflict of interest.

\section{References}

1. Balboa, E.M.; Conde, E.; Soto, M.L.; Pérez-Armada, L.; Domínguez, H. Cosmetics from marine sources. In Handbook of Marine Biotechnology; Kim, S.K., Ed.; Springer: Berlin/Heidelberg, Germany, 2015.

2. Aranaz, I.; Acosta, N.; Civera, C.; Elorza, B.; Mingo, J.; Castro, C.; Gandía, M.D.L.L.; Caballero, A.H. Cosmetics and cosmeceutical applications of chitin, chitosan and their derivatives. Polymers 2018, 10, 213. [CrossRef]

3. Brandt, F.S.; Cazzaniga, A.; Hann, M. Cosmeceuticals: Current trends and market analysis. Semin. Cutan. Med. Surg. 2011, 30, 141-143. [CrossRef]

4. Morganti, P.; Coltelli, M.-B. A new carrier for advanced cosmeceuticals. Cosmetics 2019, 6, 10. [CrossRef]

5. Sorg, O.; Antille, C.; Kaya, G.; Saurat, J.H. Retinoids in cosmeceuticals. Dermatol. Ther. 2006, 19, 289-296. [CrossRef] [PubMed]

6. Gao, X.H.; Zhang, L.; Wei, H.; Chen, H.D. Efficacy and safety of innovative cosmeceuticals. Clin. Dermatol. 2008, 26, 367-374. [CrossRef]

7. Cosmetic Europe. Socio-Economic Contribution of the European Cosmetics Industry. 2019. Available online: https: / / www.cosmeticseurope.eu/files/4715/6023/8405/Socio-Economic_Contribution_of_the_European_Cosmetics_Industry_ Report_2019.pdf. (accessed on 3 March 2021).

8. Cosmeceuticals Market Outlook 2020. RNCOS E.-Services Pvt. Ltd.; July 2017. Available online: http:/ /www.giiresearch.com/ report/rnc263147-global-cosmeceutical-market-outlook.html (accessed on 15 April 2021).

9. Liobikienè, G.; Bernatonienè, J. Why determinants of green purchase cannot be treated equally? The case of green cosmetics: Literature review. J. Clean. Prod. 2017, 162, 109-120. [CrossRef]

10. CBINSIGHTS. Available online: https://www.cbinsights.com/research/report/beauty-trends-2019/\#global (accessed on 23 March 2021).

11. Boziaris, I.S. Food ingredients from the marine environment. Marine biotechnology meets food science and technology. Front. Mar. Sci. 2014, 1, 66. [CrossRef]

12. Pereira, L. Seaweeds as source of bioactive substances and skin care therapy. Cosmeceuticals Algotheraphy Thalassother. 2018, 5, 68. [CrossRef]

13. Martins, A.; Vieira, H.; Gaspar, H.; Santos, S. Marketed marine natural products in the pharmaceutical and cosmeceutical industries: Tips for success. Mar. Drugs 2014, 12, 1066-1101. [CrossRef]

14. Kim, S.K.; Mendis, E. Bioactive compounds from marine processing byproducts-A review. Food Res. Int. 2006, $39,383-393$. [CrossRef]

15. Regulation (EU) No 1380/2013 of the European Parliament and of the Council of the European Union. Available online: https: / / eur-lex.europa.eu/LexUriServ/LexUriServ.do?uri=OJ:L:2013:354:0022:0061:EN (accessed on 30 March 2021).

16. United Nations. Sustainable Development Goals. Available online: https://sdgs.un.org/es/goals (accessed on 10 February 2021).

17. McCullough, J.L.; Kelly, K. Prevention and treatment of skin aging. Ann. N. Y. Acad. Sci. 2006, 1067, 323-331. [CrossRef] [PubMed]

18. Gervason, S.; Napoli, M.; Dreux-Zhiga, A.; Lazzarelli, C.; Garcier, S.; Briand, A.; Filaire, E. Attenuation of negative effects of senescence in human skin using an extract from Sphingomonas hydrophobicum: Development of new skin care solution. Int. J. Cosmet. Sci. 2019, 41, 391-397. [PubMed]

19. Guillerme, J.-B.; Couteau, C.; Coiffard, L. Applications for marine resources in cosmetics. Cosmetics 2017, 4, 35. [CrossRef]

20. Lodish, H.; Berk, A.; Zipursky, S.L.; Matsdaira, P.; Baltimore, D.; Darnell, J. Section 22.3 Collagen: The fibrous proteins of the matrix. In Molecular Cell Biology, 4th ed.; W. H. Freeman: New York, NY, USA, 2000. Available online: https://www.ncbi.nlm.nih. gov/books/NBK21582/.

21. Bailey, A.J.; Paul, R.G.; Knott, L. Mechanisms of maturation and ageing of ollagen. Mech. Ageing Dev. 1988, 106, 1-56. [CrossRef]

22. Bailey, A.J. Molecular mechanisms of ageing in connective tissues. Mech. Ageing Dev. 2001, 122, 735-755. [CrossRef]

23. Brunt, E.G.; Burgess, J.G. The promise of marine molecules as cosmetic active ingredients. Int. J. Cosmet. Sci. 2018, 40, 1-15. [CrossRef]

24. Secchi, G. Role of protein in cosmetics. Clin. Dermatol. 2008, 26, 321-325. [CrossRef]

25. Zhu, S.; Yuan, Q.; Yin, T.; You, J.; Gu, Z.; Xiong, S.; Hu, Y. Self-assembly of collagen-based biomaterials: Preparation, characterizations and biomedical applications. Mater. Chem. 2018, 6, 2650-2676. [CrossRef] 
26. Benjakul, S.; Nalinanon, S.; Shahidi, F. Fish collagen. In Food Biochemistry and Food Processing, 2nd ed.; Simpson, B.K., Ed.; Wiley-Blackwell: Hoboken, NJ, USA, 2012; pp. 365-387.

27. Ávila-Rodríguez, M.I.; Rodríguez-Barroso, L.G.; Sánchez, M.L. Collagen: A review on its sources and potential cosmetic applications. Cosmet Dermatol. 2017, 17, 20-26. [CrossRef]

28. Alves, A.L.; Marques, A.L.P.; Martins, E.; Silva, T.H.; Reis, R.L. Cosmetic potential of marine fish skin collagen. Cosmetics 2017, 4 , 39. [CrossRef]

29. Allard, R.; Malak, N.A.; Huc, A. Collagen Product Containing Collagen of Marine Origin with a Low Odor and Preferably with Improved Mechanical Properties, and Its Use in the Form of Cosmetic or Pharmaceutical Compositions or Products. U.S. Patent 6,660,280, 9 December 2003.

30. Gómez-Guillén, M.C.; Giménez, B.; López-Caballero, M.E.; Montero, M.P. Functional and bioactive properties of collagen and gelatin from alternative sources: A review. Food Hydrocol. 2011, 25, 1813-1827. [CrossRef]

31. GME Market Data. Official Website of GMEeGelatin Manufacturers of Europe. GME Market Data: Brussels, Belgium. 2021. Available online: http:/ / www.gelatine.org (accessed on 10 February 2021).

32. Stevens, J.R.; Newton, R.W.; Tlusty, M.; Little, D.C. The rise of aquaculture by-products: Increasing food production, value, and sustainability through strategic utilisation. Mar. Policy 2018, 90, 115-124. [CrossRef]

33. Jimbo, N.; Kawada, C.; Nomura, Y. Optimization of dose of collagen hydrolysate to prevent UVB-irradiated skin damage. Biosci. Biotechnol. Biochem. 2016, 80, 356-359. [CrossRef] [PubMed]

34. Zhuang, Y.; Hou, H.; Zhao, X.; Zhang, Z.; Livol, B. Effects of collagen and collagen hydrolysate from jellyfish (Rhopilema esculentum) on mice skin photoaging induced by UV irradiation. J. Food Sci. 2009, 74, H183-H188. [CrossRef] [PubMed]

35. Sotelo, C.G.; Blanco, M.; Ramos-Ariza, P.; Pérez-Martín, R.I. Characterization of collagen from different discarded fish species of the west coast of the Iberian Peninsula. J. Aquat. Food Prod. Technol. 2016, 25, 388-399. [CrossRef]

36. Blanco, M.; Sotelo, C.G.; Pérez-Martín, R.I. New strategy to cope with common fishery policy landing obligation: Collagen extraction from skins and bones of undersized hake. Polymers 2019, 11, 1485. [CrossRef]

37. Pati, F.; Adhikari, B.; Dhara, S. Isolation and characterization of fish scale collagen of higher thermal stability. Bioresour Technol. 2010, 101, 3737-3742. [CrossRef]

38. Jeong, H.S.; Venkatesan, J.; Kim, S. Isolation and characterization of collagen from marine fish (Thunnus obesus). Biotechnol. Bioprocess Eng. 2013, 18, 1185-1191. [CrossRef]

39. Zelechowska, E.; Sadowska, M.; Turk, M. Isolation and some properties of collagen from the backbone of Baltic cod (Gadus morhua). Food Hydrocol. 2010, 24, 325-329. [CrossRef]

40. Zhang, F.; Wang, A.; Lijun, S.; He, S.; Shao, L. Preparation and Characterisation of Collagen from Freshwater Fish Scales. Food Nutr. Sci. 2011, 2, 818-823. [CrossRef]

41. Swatschek, D.W.; Schatton, J.; Kellermann, W.; Muller, E.G.; Kreuter, J. Marine sponge collagen: Isolation, characterization and effects on the skin parameters surface-pH, moisture and sebum. Eur. J. Pharm. Biopharm. 2002, 53, 107-113. [CrossRef]

42. Venkatesan, J.; Anil, S.; Kim, S.-K.; Shim, M.S. Marine fish proteins and peptides for cosmeceuticals: A review. Mar. Drugs 2017, 15, 143. [CrossRef] [PubMed]

43. Lødemel, J.B.; Egge-Jacobsen, W.; Olsen, R.L. Detection of TIMP-2-like protein in Atlantic cod (Gadus morhua) muscle using two-dimensional real-time reverse zymography. Comp. Biochem. Physiol. B Biochem. Mol. Biol. 2004, 139, 253-259. [CrossRef] [PubMed]

44. KliniPharm. Available online: http://www.klinipharm.com/ (accessed on 24 March 2021).

45. The Organic Pharmacy. Available online: http:/ / www.theorganicpharmacy.com/ (accessed on 24 March 2021).

46. Finn Canada. Available online: https:/ / www.finncanada.com/ (accessed on 24 March 2021).

47. Zeinali, F.; Homaei, A.; Kamrani, E. Sources of marine superoxide dismutases: Characteristics and applications. Int. J. Biol. Macromol. 2015, 79, 627-637. [CrossRef]

48. Petersen, S.V.; Oury, T.D.; Ostergaard, L.; Valnickova, Z.; Wegrzyn, J.; Thøgersen, I.B.; Enghild, J.J. extracellular superoxide dismutase (EC-SOD) binds to type I collagen and protects against oxidative fragmentation. J. Biol. Chem. 2004, 279, 13705-13710. [CrossRef]

49. Tetra SOD. Available online: https://www.tetrasod.com (accessed on 25 March 2021).

50. Ziboh, V.A.; Miller, C.C.; Cho, Y. Metabolism of polyunsaturated fatty acids by skin epidermal enzymes: Generation of anti inflammatory and antiproliferative metabolites. Am. J. Clin. Nutr. 2000, 71 (Suppl. 1), 361-366. [CrossRef]

51. Kim, S.K.; Ravichandran, Y.D.; Khan, S.B.; Kim, Y.T. Prospective of the cosmeceuticals derived from marine organisms. Biotechnol. Bioprocess Eng. 2008, 13, 511-523. [CrossRef]

52. Messyasz, B.; Michalak, I.; Leska, B.; Schroeder, G.; Górka, B.; Korzeniowska, K.; Lipok, J.; Wieczorek, P.P.; Rój, E.; Wilk, R.; et al. Valuable natural products from marine and freshwater macroalgae obtained from supercritical fluid extracts. J Appl Phycol. 2018, 30, 591-603. [CrossRef]

53. Couteau, C.; Coiffard, L. Phycocosmetics and other marine cosmetics, specific cosmetics formulated using marine resources. Mar. Drugs 2020, 18, 322. [CrossRef]

54. Korkina, L.; Kostyuk, V.; Potapovich, A.; Mayer, W.; Talib, N.; de Luca, C. Secondary plant metabolites for sun protective cosmetics: From pre-selection to product formulation. Cosmetics 2018, 5, 32. [CrossRef] 
55. Lozano-Grande, M.A.; Gorinstein, S.; Espitia-Rangel, E.; Dávila-Ortiz, G.; Martínez-Ayala, A.L. Plant sources, extraction methods, and uses of squalene. Int. J. Agron. 2018, 2018, 1-13. [CrossRef]

56. De Carvalho, C.C.C.R.; Caramujo, M.J. Carotenoids in aquatic ecosystems and aquaculture: A colorful business with implications for human health. Front. Mar. Sci. 2017, 4. [CrossRef]

57. Novoveská, L.; Ross, M.E.; Stanley, M.S.; Pradelles, R.; Wasiolek, V.; Sassi, J.-F. Microalgal carotenoids: A review of production, current markets, regulations, and future direction. Mar. Drugs 2019, 17, 640. [CrossRef]

58. Koller, M.; Muhr, A.; Braunegg, G. Microalgae as versatile cellular factories for valued products. Algal Res. 2014, 6, 52-63. [CrossRef]

59. Hamed, I. The evolution and versatility of microalgal biotechnology: A review. Compr. Rev. Food Sci. Food Saf. 2016, 15, 1104-1123. [CrossRef] [PubMed]

60. Eclae. Available online: https:/ /www.eclae.com/en/ (accessed on 25 March 2021).

61. Poojary, M.M.; Barba, F.J.; Aliakbarian, B.; Donsì, F.; Pataro, G.; Dias, D.A.; Juliano, P. Innovative alternative technologies to extract carotenoids from microalgae and seaweeds. Mar. Drugs 2016, 14, 1-34. [CrossRef] [PubMed]

62. Suryani, D.; Sari, P.; Saputra, E.; Alamsjah, M.A. Potential of Fucoxanthin Content in Sargassum Sp. on Sunscreen Cream Preparation. Int. J. Recent Technol. 2019, 6, 448-451.

63. Vázquez, J.A.; Rodríguez-Amado, I.; Montemayor, M.I.; Fraguas, J.; González, M.D.P.; Murado, M.A. Chondroitin sulfate, hyaluronic acid and chitin/chitosan production using marine waste sources: Characteristics, applications and eco-friendly processes: A. review. Mar. Drugs 2013, 11, 747-774. [CrossRef]

64. Sun, M.L.; Zhao, F.; Shi, M.; Zhang, X.Y.; Zhou, B.C.; Zhang, Y.Z.; Chen, X.L. Characterization and biotechnological potential analysis of a new exopolysaccharide from the arctic marine bacterium polaribacter sp. SM1127. Sci. Rep. 2015, 5, 1-12. [CrossRef]

65. Costaouec, T.L.; Cérantola, S.; Ropartz, D.; Ratiskol, J.; Sinquin, C.; Colliec-Jouault, S.; Boisset, C. Structural data on a bacterial exopolysaccharide produced by a deep-sea Alteromonas macleodii strain. Carb. Polym. 2019, 1, 49-59.

66. Unipex. Available online: http:/ / unipex.com (accessed on 26 March 2021).

67. Bioalvo. Available online: http:/ / www.bioalvo.com (accessed on 26 March 2021).

68. Lipotec. Available online: https:/ / www.lipotec.com (accessed on 26 March 2021).

69. Estée Lauder. Available online: https:/ / www.esteelauder.es/ (accessed on 26 March 2021).

70. Poli, A.; Anzelmo, G.; Nicolaus, B. Bacterial exopolysaccharides from extreme marine habitats: Production, characterization and biological activities. Mar. Drugs 2010, 8, 1779-1802. [CrossRef]

71. Algenist. Available online: https:/ / www.algenist.com/pages/alguronic-acid (accessed on 26 March 2021).

72. Codif R\&N. Available online: https:/ / codif-reserche-et-nature.com (accessed on 26 March 2021).

73. Jahan, A.; Ahmad, I.Z.; Fatima, N.; Ansari, V.A.; Akhtar, J. Algal bioactive compounds in the cosmeceutical industry: A review. Phycologia 2017, 56, 410-422. [CrossRef]

74. Bae, S.B.; Nam, H.C.; Park, W.H. Electrospraying of environmentally sustainable alginate microbeads for cosmetic additives. Int. J. Biol. Macromol. 2019, 133, 278-283. [CrossRef] [PubMed]

75. Giji, S.; Arumugam, M. Isolation and characterization of hyaluronic acid from marine organisms. Adv. Food Nutr. Res. 2014, 72, 61-77. [CrossRef] [PubMed]

76. Edgar, S.; Hopley, B.; Genovese, L.; Sibilla, S.; Laight, D.; Shute, J. Effects of collagen-derived bioactive peptides and natural antioxidant compounds on proliferation and matrix protein synthesis by cultured normal human dermal fibroblasts. Sci. Rep. 2018, 8, 1-13. [CrossRef]

77. Murado, M.A.; Montemayor, M.I.; Cabo, M.I.; Vázquez, J.A.; González, M.P. Optimization of extraction and purification process of hyaluronic acid from fish eyeball. Food Bioprod. Process. 2012, 90, 491-498. [CrossRef]

78. Vázquez, J.A.; Montemayor, M.I.; Fraguas, J.; Murado, M.A. Hyaluronic acid production by Streptococcus zooepidemicus in marine by-products media from mussel processing wastewaters and tuna peptone viscera. Microb. Cell Factories 2010, 9, 1-10. [CrossRef] [PubMed]

79. Kanoh, S.; Maeyama, K.; Tanaka, R.; Takahashi, T.; Aoyama, M.; Watanabe, M.; Niwa, E. Possible utilization of the pearl oyster phospholipid and glycogen as a cosmetic material. Develop. Food Sci. 2004, 42, 179-190.

80. Kim, S.K. Marine cosmeceuticals. J. Cosm. Derm. 2014, 13, 56-67. [CrossRef] [PubMed]

81. Kang, H.Y.; Lee, Y.-J.; Lee, W.-C.; Kim, H.C.; Kang, C.-K. Gross biochemical and isotopic analyses of nutrition-allocation strategies for somatic growth and reproduction in the bay scallop Argopecten irradians newly introduced into Korean waters. Aquaculture 2019, 503, 156-166. [CrossRef]

82. Casadidio, C.; Peregrina, D.V.; Gigliobianco, M.R.; Deng, S.; Censi, R.; Di Martino, P. Chitin and chitosans: Characteristics, eco-friendly processes, and applications in cosmetic science. Mar. Drugs 2019, 17, 369. [CrossRef] [PubMed]

83. Kwak, J.Y.; Seok, J.K.; Suh, H.J.; Choi, Y.H.; Hong, S.S.; Kim, D.S.; Boo, Y.C. Antimelanogenic effects of luteolin 7-sulfate isolated from Phyllospadix iwatensis Makino. Br. J. Dermatol. 2016, 175, 501-511. [CrossRef] [PubMed]

84. Wang, L.; Cui, Y.R.; Yang, H.; Lee, H.G.; Ko, J.; Jeon, Y. A mixture of seaweed extracts and glycosaminoglycans from sea squirts inhibits $\alpha$-MSH-induced melanogenesis in B16F10 melanoma cells. Fish. Aquat. Sci. 2019, 3, 1-8. [CrossRef]

85. Lee, H.Y.; Jang, E.J.; Bae, S.Y.; Jeon, J.E.; Park, H.J.; Shin, J.; Lee, S.K. Anti-melanogenic activity of gagunin d, a highly oxygenated diterpenoid from the marine sponge Phorbas Sp., via modulating tyrosinase expression and degradation. Mar. Drugs 2016, 14, 212. [CrossRef] 
86. Lawrence, K.P.; Long, P.F.; Young, A.R. Mycosporine-like amino acids for skin photoprotection. Curr. Med. Chem. 2017, 25, 5512-5527. [CrossRef]

87. Corinaldesi, C.; Barone, G.; Marcellini, F.; Dell'Anno, A.; Danovaro, R. Marine microbial-derived molecules and their potential use in cosmeceutical and cosmetic products. Mar. Drugs 2017, 15, 118. [CrossRef]

88. Gelyma. Available online: http:/ /www.gelyma.com/helionori.html (accessed on 26 March 2021).

89. Mibelle Biochemistry Group. Available online: https:/ / mibellebiochemistry.com/helioguardtm-365 (accessed on 26 March 2021).

90. Pimentel, F.B.; Alves, R.C.; Rodrigues, F.; Oliveira, M.B. Macroalgae-derived ingredients for cosmetic industry-An update. Cosmetics 2018, 5, 2. [CrossRef]

91. Ferdouse, F.; Holdt, S.L.; Smith, R.; Murúa, P.; Yang, Z. The global status of seaweed production, trade and utilization. FAO Globefish Res. Programme 2018, 124, 120.

92. Werner, A.; Clarke, D.; Kraan, S. Strategic Review of the Feasibility of Seaweed Aquaculture in Ireland. NDP Marine RTDI Desk Study Series; Marine Institute: Galway, Ireland, 2004; ISSN 16495063.

93. Buschmann, A.H.; Camus, C.; Infante, J.; Neori, A.; Israel, A.; Hernández-González, M.C.; Pereda, S.V.; Gomez-Pinchetti, J.L.; Golberg, A.; Tadmor-Shalev, N.; et al. Seaweed production: Overview of the global state of exploitation, farming and emerging researchactivity. Eur. J. Phycol. 2017, 52, 391-406. [CrossRef]

94. Morais, T.; Cotas, J.; Pacheco, D.; Pereira, L. Seaweeds compounds: An eco sustainable source of cosmetic ingredients? Cosmetics 2021, 8, 8. [CrossRef]

95. Torres, P.; Santos, J.P.; Chow, F.; dos Santos, D.Y.A.C. A comprehensive review of traditional uses, bioactivity potential, and chemical diversity of the genus Gracilaria (Gracilariales, Rhodophyta). Algal Res. 2019, 37, 288-306. [CrossRef]

96. Fitton, J.H.; Irhimeh, M.; Falk, N. Macroalgal fucoidan extracts: A new opportunity for marine cosmetics. Cosmet. Toilet. 2007, 122, 8.

97. Leal, M.C.; Rocha, R.J.M.; Rosa, R.; Calado, R. Aquaculture of marine non-food organisms: What, why and how? Rev. Aquacult. 2018, 10, 400-423. [CrossRef]

98. Tiller, R.G.; Mork, J.; Richards, R.; Eisenhauer, L.; Liu, Y.; Nakken, J.F.; Borgersen, A.L. Something fishy: Assessing stakeholder resilience to increasing jellyfish (Periphylla periphylla) in Trondheimsfjord, Norway. Mar. Policy 2014, 46, 72-83. [CrossRef]

99. Gravili, Z. Jelly surge in the Mediterranean Sea: Threat or opportunity? Medit. Mar. Sci. 2020, 21, 11-21. [CrossRef]

100. Blanco, M. Valorización de Descartes y Subproductos de Pintarroja (Scyliorhinus canicula). Ph.D. Thesis, Universidad de Vigo, Vigo, Spain, December 2015.

101. FAO. El Estado Mundial de la Pesca y la Acuicultura; FAO: Rome, Italy, 2020.

102. Gilman, E.; Huntington, T.; Kennelly, S.J.; Suuronen, P.; Chaloupka, M.; Medley, P. A third assessment of global marine fisheries discards. In FAO Fisheries and Aquaculture Technical Paper No. 633; Pérez Roda, M.A., Ed.; FAO: Rome, Italy, 2019 ; 78 p; Licence: CC BY-NC-SA 3.0 IGO.

103. Caruso, G.; Floris, R.; Serangeli, C.; Di Paola, L. Fishery wastes as a yet undiscovered treasure from the sea: Biomolecules sources, extraction methods and valorization. Mar. Drugs 2020, 18, 622. [CrossRef]

104. Khawli, F.A.; Pateiro, M.; Domínguez, R.; Lorenzo, J.M.; Gullón, P.; Kousoulaki, K.; Ferrer, E.; Berrada, H.; Barba, F.J. Innovative Green technologies of intensification for valorization of seafood and their by-products. Mar. Drugs 2019, 17, 689. [CrossRef] [PubMed]

105. Rustad, T.; Storrø, I.; Slizyte, R. Possibilities for the utilisation of marine by-products. Int. J. Food Sci. 2011, 46, 2001-2014. [CrossRef]

106. Vázquez, J.A.; Fraguas, J.; Novoa-Carballal, R.; Reis, R.L.; Pérez-Martín, R.I.; Valcarcel, J. Optimal isolation and characterisation of chondroitin sulfate from rabbit fish (Chimaera monstrosa). Carb. Polym. 2019, 210, 302-313. [CrossRef]

107. Bruno, S.F.; Ekorong, F.J.A.A.; Karkal, S.S.; Cathrine, M.S.B.; Kudre, T.G. Green and innovative techniques for recovery of valuable compounds from seafood by-products and discards: A review. Trends Food Sci. Technol. 2019, 85, 10-22. [CrossRef]

108. BE-FAIR Project. Begin and Environmentally Friendly Fish Processing Practices to Provide Added Value and Innovative Solutions for A Responsable and Sustainable Management or Fisheries; Life iSEAS: Madrid, Spain, 2008; LIFE05 ENV/E000267.

109. Copalis Sea Solutions. Available online: https://www.copalis.fr (accessed on 29 March 2021).

110. Sea Energy. Available online: http:/ / seanergy.es/ (accessed on 29 March 2021).

111. Kenney\&Ross Limited. Available online: http:/ / kenneyandross.com/ (accessed on 29 March 2021). 